\title{
IMPLEMENTASI PERTANGGUNGJAWABAN PELAKU TINDAK PIDANA MEMPERNIAGAKAN BAGIAN-BAGIAN TUBUH SATWA YANG DILINDUNGI
}

(Studi Putusan Nomor: 1027/Pid.Sus/LH/2018/PN.Tjk.)

\author{
Parama Nawa Yoga ${ }^{1}$, Hutomo Wahyu Adi Santoso ${ }^{2}$, Ujang Tommy ${ }^{3}$ \\ Fakultas Hukum Universitas Bandar Lampung \\ Jl. ZA Pagar Alam No 26 Labuhan Ratu Bandar Lampung \\ Email: nawavoganteng@gmail.com; \\ hutomo.wahyu@ubl.ac.id; ujang.tommy@ubl.ac.id
}

\begin{abstract}
ABSTRAK
Ilegal wildlife trade is a serious threat to the conservation of wildlife in Indonesia. Wildlife illegally traded based on the facts found in the wield are mostly caught from the wild, instead of breeding. Natural Resources Conservation Center as an institution that has an important role in rescue efforts are strategic and Endangered species protection of law number 5 of 1990 on Conservation of Biological Resources and Ecosystem. The problem in this study is whether the factors causing the perpetrators to commit criminal acts trade the body parts of the protected animals, and how they are accountable and what efforts to overcome them. Juridical normative and empirical research methods, using secondary and primary data, obtained from library studies and field studies. Based on the results of research and discussion, it is known that the factors causing the perpetrators to commit criminal acts trade the body parts of protected animals, namely economic factors, environmental factors, and factors of public knowledge of the prohibition. The responsibility of the perpetrator of the crime of trading the body parts of the protected animal has been decided by the defendant proven guilty and sentenced to imprisonment for: 3 (three) years and a fine of Rp. 50,000,000 (fifty million rupiah). One of the factors that caused the criminal act to trade the body parts of the protected animals was due to the lack of socialization or knowledge of the community against the prohibition on killing / selling wild animals.
\end{abstract}

\section{Keywords: Accountability, Administration, Protected Animals}

\section{PENDAHULUAN}

Perdagangan ilegal satwa liar yang juga merupakan kejahatan yang telah terorganisir dengan rapi, memiliki jaringan luas dan kuat serta dengan modus pemilikan, pemeliharaan, penyelundupan hewan yang dilindungi yang terus berkembang. Dalam beberapa kasus perdagangan ilegal satwa liar justru dilakukan oleh eksportir satwa liar yang memiliki izin resmi.

Sumber daya alam berdasarkan jenisnya dapat dibedakan menjadi dua yaitu, sumber daya alam hayati dan sumber daya alam non hayati/abiotik. Sumber daya alam nabati (tumbuhan) dan sumber daya alam hewani (satwa) yang bersama dengan unsur non hayati disekitarnya secara keseluruhan membentuk ekosistem.
Menurut Supardi, (2008:95) sumber daya alam merupakan karunia Allah SWT yang harus dikelola dengan bijaksana, sebab sumber daya alam memiliki keterbatasan penggunaanya.

Selanjutnya menurut A Fatchan (2013:244) menyatakan bahwa sumber daya alam adalah segala sesuatu yang ada dilingkungan alam yang dapat dimanfaatkan untuk berbagai kepentingan dan kebutuhan hidup manusia agar lebih sejahtera.

Widada (2006:26) menyatakan negara republik indonesia merupakan negara yang memiliki kekayaan keanekaragaman hayati yang menjadi sumber daya alam khas Negara Indonesia,mengingat kawasan hutan, laut serta habitat satwa di Indonesia mencakup sangat banyak jenis satwa yang ada, kondisi satwa yang ada di Indonesia 
memiliki keunikan tersendiri. Indonesia secara geografis terletak pada perbatasan lempeng Asia Purba dan lempeng Australia itu menyebabkan perbedaan tipe satwa dikawsan barat, tengah dan timur Indonesia".

Keanekaragaman satwa di Indonesia juga disebabkan wilayah yang luas dan ekosistem yang beragam karena hal tersebut wilayah indonesia memiliki berbagai jenis satwa khas atau endemik yang hanya terdapat di Indonesia, sehingga Indonesia memiliki berbagai jenis satwa yang dilindungi. Kekayaan keanekaragaman hayati yang dimiliki Indonesia ini diikuti dengan ancaman kepunahan keanekaragaman hayati pada satwa itu sendiri.

Kerusakan sumber daya alam Indonesia tampak makin mencemaskan dengan pesatnya daya pengelolaan isi sumber daya alam indonesia tampak makin mencemaskan dengan pesatnya daya pengolahan isi sumber daya alam serta pemanfaatan secara berlebihan yang tidak diikuti dengan keamanan yang ketat serta kurangnya pengetahuan masyarakat tentang norma-norma yang telah ditetapkan secara yuridis.

Kekayaan keanegaragaman hayati di Indonesia sangat mengkhawatirkan baik itu dari alam maupun dari tangan manusia itu sendiri, untuk itu pemerintah melakukan pengolahan sumber daya alam sebagai ekosistem secara adil, demokratis, efesien, dan profesional guna menjamin keterlanjutan fungsi lingkungan hidup dan manfaatnya untuk kesejahteraan bagi negara dan masyarakat.

Ancaman penurunan populasi dan kepunahan satwa di Indonesia terus berlangsung, penyebab utama kepunahan satwa diantaranya adalah terfragmentasinya habitat tempat hidup, pemanfaatan secara berlebihan dan perburuan serta perdagangan ilegal, perburuan dan perdagangan ilegal satwa terus berlangsung memenuhi permintaan pasar antara lain digunakan sebagai peliharaan, dikonsumsi dan dijadikan bahan obat tradisional.

Pengetahuan yang kurang dan nilai ekonomis yang tinggi terhadap satwa yang dilindungi tersebut juga menjadi penyebab masih maraknya perdagangan liar hingga saat ini. Perburuan tersebut sangat merugikan bagi Negara dan telah melanggar ketentuan yang telah ditetapkan Negara.

Salah satu upaya yang dilakukan pemerintah untuk menanggulangi dan mencegah bahaya kepunahan tumbuhan dan satwa yang hidup di alam liar dengan menerbitkan suatu Undang-Undang pada tanggal 10 Agustus tahun 1990 yang mengatur konservasi sumber daya alam, yakni Undang-Undang Nomor 5 Tahun 1990 tentang Konservasi Sumber Daya Alam Hayati dan Ekosistemnya. Yang memuat pengertian - pengertian tentang konsep - konsep yang relevan dalam rangka konservasi sumber daya alam dan ekosistemnya. Beberapa diantara konsep itu, perumusannya akan dikutip disini, yakni konservasi sumber daya alam hayati, ekosistem sumber daya alam hayati, kawasan suaka alam, cagar biosfer, kawasan pelestarian alam, taman nasional, taman hutan raya, dan taman wisata alam (Takdir Rahmadi. 2012:181).

Berdasarkan Undang-Undang tersebut peburuan, perdagangan satwa dilindungi merupakan perbuatan yang dilarang. Pasal 21 ayat (2) Undang-Undang Nomor 5 Tahun 1990 menyatakan setiap orang dilarang untuk menangkap, melukai, membunuh, menyimpan, memiliki, memelihara, mengangkut, dan memperniagakan satwa yang dilindungi dalam keadaan hidup. Menyimpan, memiliki, memelihara, mengangkut, dan memperniagakan satwa yang dilindungi dalam keadaan mati. Mengeluarkan satwa yang dilindungi dari suatu tempat di Indonesia ke tempat lain di dalam atau di luar Indonesia.

Memperniagakan, menyimpan, atau memiliki kulit, tubuh, atau bagian-bagian lain satwa yang dilindungi atau barang- 
barang yang dibuat dari bagian- bagian tersebut atau mengeluarkanya dari suatu tempat di Indonesia ke tempat lain di dalam atau di luar Indonesia. Mengambil, merusak, memusnahkan, memperniagakan, menyimpan atau memiliki telur dan atau sarang satwa yang dilindungi". Pasal 40 ayat (2) Undang-Undang Nomor 5 Tahun 1990 menyatakan "Barangsiapa dengan sengaja melakukan pelanggaran terhadapketentuan sebagaimana dimaksud dalam Pasal 21 ayat (1) dan ayat (2) serta Pasal 33 ayat (3) dipidana dengan pidana penjara paling lama 5 (lima) tahun dan denda paling banyak Rp100.000.000,00 (seratus juta rupiah).

Teori "negara hukum kesejahteraan" memberikan suatu kesadaran terhadap masyarakat agar dapat terwujutnya negara yang sejahtera, selanjutnya teori "hukum pembangunan" yang merupakan peran fungsi hukum untuk membuat suatu pondasi yang kuat dalam pembangunan nasional, serta teori "sistem hukum" yang membuat daya dorong terhadap perbuatanperbuatan manusia agar menjadi lebih berguna dan memperlakukan lingkungan sekitarnya dengan baik, sehingga dapat terciptanya lingkungan yang sehat dan bersih.

Pada Peraturan Pemerintah Nomor 16 Tahun 2015 tentang Kementerian Lingkungan Hidup Dan Kehutanan dalam Pasal 3 adalah satu fungsi Kementerian Lingkungan Hidup Dan Kehutanan, koordinasi dan sinkronisasi pelaksanaan kebijakan dibidang tata lingkungan, pengelolaan keanekaragaman hayati, peningkatan daya dukung daerah aliran sungaidan hutan lindung, peningkatan kualitas fungsi lingkungan, pengendalian pencemaran dan kerusakan lingkungan, pengendalian perubahan iklim, pengendalian kebakaran hutan dan lahan, kemitraan lingkungan, serta penurunan gangguan, ancaman dan pelanggaran hukum bidang lingkungan hidup dan kehutanan.

Oleh karena itu untuk memberi efek jera pada pelaku dalam mata rantai kejahatan dibidang konservasi sumberdaya alam hayati dan ekosistemya, maka penegak hukum juga perlu mendasarkan penanganan suatu perbuatan kejahatan ini dengan peraturan perundang-undangan yang terpadu.

Upaya menempatkan masing-masing lembaga penyidik sesuai dengan kedudukan masing-masing sebagaimana arahan undang-undang sehingga dikemudian hari tidak lagi muncul tarik menarik dalam menjalakan penyidikan dan terpentik sistem penegakan hukum yang selama ini telah dibangun dapat berdiri kokoh oleh pemerintah khususnya dalam penegakan hukum di Indonesia". Kitab Undang-Undang Hukum Acara Pidana (KUHAP) memberi definisi penyidikan sebagaimana Pasal 1 ayat (1) "Penyidik adalah Pejabat Polisi Negara Republik Indonesia atau Pejabat Pegawai Negeri Sipil tertentu yang diberi wewenang khusus oleh undang-undang untuk melakukan penyidikan".

Agar tidak terjadi tumpang tindih kewenagan dalam melaksanakan penyidikan antara Penyidik Pegawai Negeri Sipil (PPNS) dengan penyidik Polri, Kitab Undang- Undang Hukum Acara Pidana (KUHAP) telah mengatur hubungan antar masing-masing instansi yaitu :

1. Untuk kepentingan penyidikan penyidik Polri memberikan petunjuk kepada penyidik PPNS untuk memberikan bantuan penyidikan yang diperlukan (Pasal 107 ayat (1) KUHAP).

2. Penyidik Pegawai Negeri Sipil tertentu, harus melaporkan kepada penyidik polri tentang adanya suatu tindak pidana yang sedang disidik, dan jika di temukan bukti yang kuat untuk mrngajukan tindak pidananya kepada penuntut umum (Pasal 107 ayat (2) KUHAP).

3. Apabila Pegawai Penyidik Negeri Sipil telah melakukan penyidikan, hasil penyidikan harus segera diserahkan pada penyidik Polri”. 
Betapapun berhasilnya polisi menangkal dan menanggulangi kejahatan dalam rangka memelihara kamtibmas (keamanan dan ketertiban masyarakat), citra negatif tetap tidak akan pernah punah. Dari semua pustaka yang menyangkut masalah polisi, baik di negara maju maupun di negara berkembang, apakah diperoleh dari hasil penelitian atau pengamatan semata-mata, hampir tidak pernah tersirat atau tersurat citra yang positif tentang polisi dalam melaksanakan tugasnya (Romli Atmasasmita. 2010:117).

Berdasarkan Studi Putusan Nomor : 1027/Pid.Sus/LH/2018/PN.Tjk. Terdakwa telah memenuhi unsur-unsur tidak pidana dengan melanggar Pasal 21 ayat (2) huruf a dan d Jo Pasal 40 ayat (2) Undang-Undang RI No. 5 Tahun 1990 Tentang Konservasi Sumber Daya Alam Hayati dan Ekosistemnya Jo Pasal 55 ayat (1) ke-1 KUHP yaitu "menangkap dan membunuh satwa yang dilindungi, serta memperniagakan bagian-bagian tubuh satwa yang dilindungi secara bersamasama' dan oleh karena itu Terdakwa dijatuhkan pidana penjara selama : 3 (tiga) tahun dan hukuman denda sebesar Rp.50.000.000,- (lima puluh juta rupiah), dengan ketentuan apabila tidak dibayar diganti dengan hukuman kurungan selama 4 (empat) bulan.

Dari uraian diatas penulis tertarik untuk mengangkatnya dalam suatu judul skripsi yang berjudul : "Implementasi Pertanggungjawaban Pelaku Tindak Pidana Memperniagakan Bagian-Bagian Tubuh Satwa Yang Dilindungi (Studi Putusan Nomor: 1027/Pid.Sus/LH/2018/PN.Tjk.)"

Berdasarkan latar belakang masalah di atas penulis merumuskan masalah sebagai berikut:

a. Mengapa Pelaku Melakukan Tindak Pidana Memperniagakan Bagian-Bagian Tubuh Satwa Yang Dilindungi?

b. Bagaimanakah Pertanggungjawaban Pelaku Tindak Pidana Memperniagakan Bagian-Bagian Tubuh Satwa Yang Dilindungi ? c. Bagaimana Upaya Menanggulangi Tindak Pidana Memperniagakan Bagian-Bagian Tubuh Satwa Yang Dilindungi ?

Metode penelitian yang digunakan dalam penelitian ini dilakukan secara yuridis normatif dan empiris, pengumpulan data menggunakan data sekunder dan primer yang diperoleh dari studi kepustakaan dan studi lapangan, setelah data terkumpul kemudian dianalisis secara kualitatif untuk mendapatkan kesimpulan. Kajian dari lingkup permasalahan dan bahasan diatas adalah mengenai Implementasi Pertanggungjawaban Pelaku Tindak Pidana Memperniagakan Bagian-Bagian Tubuh Satwa Yang Dilindungi.

\section{PEMBAHASAN}

\section{A. Faktor Penyebab Pelaku Melakukan Tindak Pidana Memperniagakan Bagian Bagian Tubuh Satwa Yang Dilindungi}

Kejahatan merupakan suatu perbuatan yang buruk, berasal dari kata jahat yang memiliki arti sangat tidak baik, sangat buruk, sangat jelek, sedangkan secara yuridis kejahatan diartikan sebagai suatu perbuatan melanggar hukum atau yang dilarang oleh undang-undang. Kejahatan merupakan suatu perbuatan suatu tindakan yang secara umum memiliki arti perbuatan yang tidak sesuai dengan hukum yang berlaku. Berdasarkan arti kejahatan berasal dari kata jahat yang mendapat awalan "ke" dan mendapat akhiran "an" yang memiliki arti sangat jelek, buruk, sangat tidak baik (tentang kelakuan, tabiat, perbuatan).

Berdasarkan hasil wawancara selama penelitian pada Balai Konservasi Sumber Daya Alam Lampung menurut Subakir faktor penyebab pelaku melakukan tindak pidana memperniagakan bagian-bagian butuh satwa yang dilindungi yaitu:

1. Jarangnya pihak berwenang yang datang ke area hutan atau perkebunan, lemahnya penegakan hukum dalam hal ini seperti para pelaku yang dihukum 
tidak sesusai dengan hukuman yang diterapkan oleh peraturan perundangundangan dan masyarakat tidak mengetahui bahwa landak adalah satwa yang dilindungi.

2. Kurangnya koordinasi dengan pihak terkait dalam hal ini kami menyadari bahwa adanya kerjasama antara BKSDA dan kepolisian dengan masyarakat, bila pelaku rela memberikan satwa kepada pihak BKSDA maka atas kerjasamanya tidak ada kelanjutan proses hukum serta kesulitan dalam penyelidikan karena beberapa saksi di tempat kejadian perkara tidak mau memberikan kesaksiannya serta kurangnya dukungan dari masyarakat setempat.

Berdasarkan hasil wawancara selama penelitian pada Polda Lampung menurut Yohanis selaku Penyidik bahwa faktor penyebab pelaku melakukan tindak pidana memperniagakan bagian-bagian butuh satwa yang dilindungi yaitu:

1. Faktor Ekonomi

Faktor ekonomi merupakan faktor yang sangat sering dijadikan pelaku sebagai alasan dalam melakukan tindak kejahatan.

2. Faktor Lingkungan

Lingkungan adalah tempat utama dalam mendukung terjadinya pola prilaku kejahatan yang dilakukan oleh seseorang. Faktor-faktor yang mempengaruhi tersebut antara lain adalah :
a. Lingkungan yang memberi kesempatan untuk melakukan kejahatan;
b. Lingkungan pergaulan yang memberi contoh dan teladan;
c. Lingkungan ekonomi, kemiskinan dan kesengsaraan;

3. Faktor faktor sarana dan fasilitas Faktor sarana dan fasilitas juga berpengaruh pada era globalisasi seperti saat sekarang ini, dan itu juga berpengaruh pada tumbuh pesatnya media elektronik khususnya media internet sehingga penyebaran informasi semakin mudah, cepat dan efektif untuk didapatkan.

Ketiga faktor ini menjadi alasan pelaku melakukan kejahatan penjualan satwa langka yang dilindungi yang mana perbuatan tersebut merupakan perbuatan melanggar hukum serta merupakan suatu perbuatan yang tidak memikirkan pentingnya kelestarian ekosistem khususnya bagi satwa-satwa yang dilindungi di Indonesia.

Berdasarkan hasil wawancara selama penelitian pada Lembaga Pemasyarakatan Kelas I Way Huwi Bandar Lampung menurut Poniman bin Rasimin selaku terdakwa mengatakan bahwa alasan ia melakukan tindak pidana memperniagakan bagian-bagian tubuh satwa yang dilindungi yaitu:

1. Faktor nilai jual yang tinggi

Karena satwa langka yang dilindungi atau bagian-bagian tubuh satwa tersebut jika diperjualbelikan memberikan keuntungan yang besar dari segi materi baik dari sang penjual ataupun pembeli.

2. Faktor hobi

Hal ini juga didorong oleh banyaknya para kolektor bagian- bagian tubuh satwa yang dilindungi, mereka tidak mengetahui dampak apa yang telah mereka lakukan dengan memperjualbelikan satwa langka yang dilindungi, kemudian mereka juga tidak memikirkan perlunya keberlangsungan hidup satwa langka yang dilindungi.

Berdasarkan penelitian di Pengadilan Negeri Kelas I A Tanjung Karang menurut Yus Enidar selaku Hakim Ketua menyatakan faktor penyebab pelaku tindak pidana memperniagakan bagian-bagian tubuh satwa yang dilindungi yaitu:

1. Faktor ketidaktahuan masyarakat Faktor ketidaktahuan masyarakat juga mempengaruhi terjadinya tindak 
kejahatan khususnya kejahatan

penjualan satwa langka yang dilindungi melalui media internet.

Kurangnya sosialisasi/punyuluhan kepada masyarakat inilah yang menyebabkan kejahatan ini terjadi masyarakat tergolong tidak tahu akan satwa yang dilindungi atau tidak dilindungi.

2. Faktor masyarakat itu sendiri

Masyarakat cendrung tidak memikirkan dampak apa yang akan terjadi dikemudian hari dengan memperjualbelikan satwa-satwa yang dilindungi, bukan hanya generasi selanjutnya tidak akan melihat langsung satwa-satwa tersebut namun akan lebih berdampak pada keadaan ekosistem yang kacau.

3. Faktor ekonomi

Sebagian besar pemburu bermotif komersial, dimana mereka melakukan perburuan secara berkelompok, satu kelompok tidak harus berjumlah banyak, satu kelompok biasanya hanya terdiri dari 3 sampai 5 orang dan juga mereka melakukan perburuan karena tergiur dengan nilai harga tinggi, ditambah lagi semua bagian tubuh harimau memiliki harga yang sangat mengiurkan, dimana dari hasil perburuan yang didapat bisa menuai hasil yang sangat memuaskan.

\section{B. Pertanggungjawaban Pelaku Tindak Pidana Memperniagakan Bagian Bagian Tubuh Satwa Yang Dilindungi}

Berdasarkan hasil wawancara selama penelitian pada Polda Lampung menurut Yohanis selaku Penyidik mengatakan bahwa perbuatan Memperniagakan Bagian-Bagian Tubuh Satwa Yang Dilindungi yang dilakukan terdakwa telah ditangkap dan ditahan dengan cara sebagai berikut :

1. Terdakwa ditangkap pada hari Selasa tanggal 5 Juni 2018 pukul 19.35 WIB berdasarkan Surat Perintah Penangkapan Nomor :
Sp.Kap/19/VI/2018/RES.5.3/Ditreskri msus tanggal 4 Juni 2018;

2. Terdakwa ditahan Penyidik berdasarkan Surat Perintah Penahanan Nomor

SP.Han/19/VI/2018/RES.5.3/Ditreskri msus tanggal 6 Juni 2018, sejak tanggal 6 Juni 2018 s/d tanggal 5 Juni 2018 di Rumah Tahanan Negara Polda Lampung;

3. Terdakwa ditahan Penyidik berdasarkan Surat Perpanjangan Penahanan No: SPP12/N.8.4/Ep.1/06/2018 Kepala Kejaksaan Tinggi Lampung, tanggal 8 Juni 2018, sejak tanggal 26 Juni 2018 s/d 4 Agustus 2018 di Rumah Tahanan Negara Polda Lampung;

4. Terdakwa ditahan Penuntut Umum berdasarkan Surat Perintah Penahanan (Tingkat Penuntutan) Nomor : PRINT5556/N.8.10/Euh.2/08/2018 tanggal 1 Agustus 2018, sejak tanggal 1 Agustus 2018 s/d tanggal 20 Agustus 2018 di Rumah Tahanan Negara (RUTAN) Kelas I Bandar Lampung di Way Hui;

5. Hakim Pengadilan Negeri Tanjung Karang berdasarkan Penetapan Nomor : $\quad$ 1027/Pid.Sus/LH/2018/PN.Tjk tanggal 13 Agustus 2018, sejak tanggal 13 Agustus 2018 sampai dengan 11 September 2018 di dalam Rumah Tahanan Negara Kelas I Bandar Lampung Way Hui;

6. Ketua Pengadilan Negeri Tanjung Karang berdasarkan Penetapan Nomor : $\quad$ 1027/Pid.Sus/LH/2018/PN.Tjk tanggal 7 September 2018, sejak tanggal 12 September 2018 sampai dengan tanggal 10 November 2018.

Berdasarkan hasil wawancara selama penelitian pada Kejaksaan Tinggi Lampung menurut Sabi' in selaku Penuntut Umum mengatakan bahwa perbuatan Memperniagakan Bagian-Bagian Tubuh Satwa Yang Dilindungi yang dilakukan terdakwa telah terbukti secara sah dan meyakinkan melakukan tindak pidana sebagaimana diatur dan diancam pidana 
dalam Pasal 21 ayat (2) huruf a dan d Jo. Pasal 40 Ayat (2) Undang-Undang Republik Indonesia Nomor 5 Tahun 1990 Tentang Konservasi Sumber Daya Alam Hayati dan Ekosistemnya Jo. Pasal 55 Ayat (1) Ke-1 KUHP, oleh karenanya menuntut agar Pengadilan Negeri Tanjung Karang yang memeriksa dan mengadili perkara ini menjatuhkan putusan sebagai berikut :

1. Menyatakan Terdakwa Poniman bin Rasimin bersalah melakukan tindak pidana "yang melakukan, yang menyuruh melakukan dan yang turut melakukan perbuata, memperniagakan, menyimpan atau memiliki kulit, tubuh atau bagianbagian satwa tersebut atau mengeluarkan dari suatu tempat Indonesia ke tempat lain di dalam atau luar Indonesia" sebagaimana dimaksud dalam Pasal 21 ayat (2) huruf d Jo. Pasal 40 ayat (2) Konservasi Sumber Daya Alam Hayati dan Ekosistemnya Jo. Pasal 55 ayat (1) ke-1 KUHP;

2 Menjatuhkan pidana penjara terhadap Terdakwa selama 3 (tiga) tahun dan

6 (enam) bulan dengan dikurangi selama terdakwa berada dalam tahanan sementara dengan perintah terdakwa tetap ditahan dan denda sebesar Rp. 50.000.000,- (lima puluh juta rupiah) subsidair masing-masing 6 (enam) bulan kurungan;

3. Menyatakan barang bukti berupa :

a) 1 (satu) lembar kulit harimau dalam keadaan utuh;

b) 1 (satu) utas tali kopling sepeda motor RX King yang digunakan untuk menjerat seekor harimau sumatera;

c) 1 (satu) unit senjata api locok rakitan;

d) Uang hasil penjualan bagian tubuh dari harimau sumatera sebesar Rp.5.000.000,- (lima juta rupiah);

4. Menetapkan agar terdakwa membayar biaya perkara sebesar Rp.2000,- (dua ribu rupiah)
Tugas utama hakim adalah menjalankan fungsi mengadili dan memutuskan perkara bertanggung jawab atas penetapan dan putusan yang dibuatnya. pertanggung jawaban tersebut berkaitan dengan substansi putusan dan danpak putusan pengadilan. suatu putusan pengadilan tidak boleh dibuat secara kebetulan atau sewenang-wenang menurut selera hakim. Hakim memang bukan corong Undang-undang tetapi juga tidak bisa diterima bahwa hakim mengadili dan memutus perkara menurut seleranya sendiri. Putusan yang baik dibuat berdasarkan analisis yang teliti, dari semua fakta-fakta persidangan yaitu informasi, alat bukti, keyakinan hakim. pertanggung jawaban hakim terhadap putusan pengadilan yang telah diputuskan di sidang pengadilan berkaitan dengan pola pikir normatif yang menguasai pemikiran hakim.

Berdasarkan hasil wawancara selama penelitian pada Pengadilan Negeri Kelas I A Tanjung Karang menurut Yus Enidar selaku Hakim Ketua mengatakan bahwa pertimbangan hakim dalam menjatuhkan pekara tindak pidana Memperniagakan Bagian-Bagian Tubuh Satwa Yang Dilindungi yang didakwa melanggar Pasal 21 ayat (2) huruf a dan d Jo. Pasal 40 ayat (2) Undang-Undang RI No.5 Tahun 1990 tentang Konservasi Sumber Daya Alam Hayati dan Ekosistemnya Jo. Pasal 55 ayat (1) ke-1 KUHP;

Dalam meminta pertanggungjawaban pidana terhadap pelaku tindak pidana perdagangan ilegal satwa liar, sudah sangat jelas dituangkan larangan apa saja yang tidak boleh dilakukan para pelaku tindak pidana perdagangan ilegal. UndangUndang Nomor 5 Tahun 1990 Tentang Konservasi Sumber Daya Alam Hayati dan Ekosistemnya Pasal 21 ayat menjelaskan bahwa:

a. Setiap orang dilarang untuk menangkap, melukai, membunuh, menyimpan, memiliki, memelihara, mengangkut, dan memperniagakan satwa yang dilindungi dalam keadaan hidup; 
b. menyimpan, memiliki, memelihara, mengangkut, dan memperniagakan satwa yang dilindungi dalam keadaan mati;

c. mengeluarkan satwa yang dilindungi dari suatu tempat di Indonesia ke tempat lain di dalam atau di luar Indonesia;

d. memperniagakan, menyimpan atau memiliki kulit, tubuh atau bagianbagian lain satwa yang dilindungi atau barang-barang yang dibuat dari bagianbagian satwa tersebut atau mengeluarkannya dari suatu tempat di Indonesia ke tempat lain di dalam atau di luar Indonesia;

e. mengambil, merusak, memusnahkan, memperniagakan, menyimpan atau memiliki telur dan/atau sarang satwa yang dilindungi.

Undang undang yang mengatur hukuman bagi pelaku tindak pidana: dituang didalam Pasal 40 ayat (2) dan (4) ayat 2 "Barangsiapa dengan sengaja melakukan pelanggaran terhadap ketentuan sebagaimana dimaksud dalam Pasal 21 ayat (1) dan ayat (2)serta Pasal 33 ayat (3) dipidana dengan pidana penjara paling lama 5 (lima) Tahun dan denda paling banyak Rp. 100.000.000,00 (seratus juta rupiah). ayat 4 "Barangsiapa karena kelalaiannya melakukan pelanggaran terhadap ketentuan sebagaimana dimaksud dalam Pasal 21 ayat (1) dan ayat (2) serta Pasal 33 ayat (3) dipidana dengan pidana kurungan paling lama 1 (satu) Tahun dan denda paling banyak Rp. 50.000.000,00 (lima puluh juta rupiah)" Dari hasil penelitian yang saya teliti ternyata pelaku tindak pidana perdagangan ilegal satwa liar yang dilindungi tidak hanya pedagang melainkan pembeli juga termasuk dalam pelaku tindak pidana perdagangan ilegal satwa liar yang dilindungi yang berstatus pemilik atau memiliki hewan yang telah dibeli berdasarkan Undang-Undang Nomor 5 Tahun 1990 Pasal 21 Ayat 2. Pertanggungjawaban pidana yang diberikan juga sama kepada pembeli dan penjual sesuai pasal 40 Ayat 2 dan 4.
Menurut Yus Enidar selaku Hakim Ketua mengatakan dalam perkara menangkap dam membunuh satwa yang dilindungi, serta memperniagakan bagianbagian tubuh satwa yang dilindungi secara bersama sama terdakwa mempertanggungjawabkan perbuatannya sesuai dengan putusan Hakim Pengadilan Negeri Kelas I A Tanjung Karang yang berbunyi :

1. Menyatakan terdakwa Poniman bin Rasimin terbukti secara sah dan meyakinkan bersalah melakkan perbuatan pidana "menangkap dan membunuh satwa yang dilindungi, serta memperniagakan bagian-bagian tubuh satwa yang dilindungi secara bersama-sama"

2. Menjatuhkan pidana terhadap terdakwa Poniman bin Rasimin oleh karena itu dengna pidana penjara selama : 3 (tiga) tahun dan hukuman denda sebesar Rp.50.000.000,- (lima puluh juta rupiah), dengan ketentuan apabila tidak dibayar diganti dengan hukuman kurungan selama 4 (bulan);

3. Menyatakan masa penangkapan dan masa penahanan yang telah dijalani terdakwa dikurangkan seluruhnya dari pidana yang dijatuhkan;

4. Menyatakan terdakwa tetap ditahan di dalam Rumah Tahanan Negara;

5. Menyatakan barang bukti berupa :

a) 1 (satu) lembar kulit harimau dalam keadaan utuh;

b) 1 (satu) unit handphone merk Nokia 105 warna biru hitam berikut SIM Card 0823-771661111;

c) Video yang diunduh pada hari kamis tanggal 14 Juni 2018 pukul 10.10 WIB di Youtube dengan url https://www.youtube.com/w atch $? v=F 14 u P 4 i k 8 G w$ dan pada hari Kamis tanggal 14 Juni 2018 pukul $\quad 10.00 \quad$ WIB https://www.youtube.com/w atch? $v=7 D L U A 0 t-53 c$;

d) 1 (satu) utas tali kopling sepeda motor RX King yang digunakan 
untuk menjerat seekor harimau sumatera;

e) Uang hasil penjualan bagian tubuh dari harimau sumatera sebesar Rp.5000.000,- (lima juta rupiah);

f) Bukti pengiriman Ahmad Irvan bin Kemas Saleh kepada Master Sembiring, S.H. pada hari Senin tanggal 30 April 2018 dan pada hari Senin tanggal 21 Mei 2018;

g) SOP pengiriman barang di PT CITRA VAN TITIPAN KILAT sub agen Way Jepara, Kabupaten Lampung Timur;

h) Tangkapan layar pengiriman Ahmad Irvan bin Kemas Abbas kepada Master Sembiring, S.H. pada hari Senin tanggal 30 April 2018 dan pada hari Senin tanggal 21 Mei 2018 yang diterima oleh Ester S, dibuka di www.tiki.id ;

i) 1 (satu) pucuk senjata api rakitan jenis locok tanpa bodi;

6. Membebankan biaya perkara kepada terdakwa sebesar Rp.7.500,- (tujuh ribu lima ratus rupiah).

\section{Upaya Menanggulangi Tindak Pidana Memperniagakan Bagian Bagian Tubuh Satwa Yang Dilindungi}

Berdasarkan hasil wawancara selama penelitian pada Pengadilan Negeri Kelas I A Tanjung Karang menurut Yus Enidar selaku Hakim Ketua mengatakan bahwa untuk menanggulangi tindak pidana memperniagakan bagian-bagian tubuh satwa yang dilindungi tersebut perlu dilakukan upaya-upaya lebih lanjut khususnya oleh pemerintah untuk mendorong konservasi dan pelestarian dari satwa- satwa liar khususnya yang dilindungi di Indonesia. Salah satunya adalah dengan menyusun berbagai kebijakan di lapangan yang dapat melengkapi ketentuan yang telah dibuat oleh CITES. Namun, sebelumnya perlu diketahui juga mengenai definisi dan tipe dari larangan mengenai satwa liar.
Larangan mengenai satwa liar (wildlife ban) adalah ketetapan resmi yang melarang perdagangan satwa liar secara komersial, baik secara individu, bagian tubuh atau produk jadi dari satwa liar. Tujuan utama dari larangan ini adalah untuk mengurangi penggunaan spesies tertentu secara komersial untuk menjaga populasi spesies tersebut. Terdapat dua tipe larangan, yaitu

1. Larangan satwa liar secara internasional oleh CITES (Convention on international trade in endangered species of wild fauna and flora). CITES muncul pada tahun 1973. CITES merupakan hasil dari kesepakatan secara internasional yang dibuat berdasar data dan informasi yang didapatkan secara ilmiah. Pada CITES ini dirumuskan tiga Appendix yaitu, Appendix 1 adalah larangan akan perdagangan spesies yang terancam punah. Appendix II melindungi spesies yang memiliki resiko terancam punah bila perdagangan tidak dikontrol dan membolehkan perdagangan dengan adanya ijin. Appendix III melindungi spesies yang diajukan oleh pihak tertentu dan memberikan ijin dengan kontrol yang tidak terlalu dibatasi seperti pada Appendix II.

2. Larangan non CITES Pemerintah memiliki peranan penting dalam memerangi perdagangan gelap satwa liar secara internasional. Larangan secara resmi yang dikeluarkan oleh pemerintah dapat membantu upaya konservasi satwa dilindungi di negara tersebut. Contohnya larangan impor unggas oleh European Union (EU) adalah salah satu larangan non CITES yang dikeluarkan untuk mengurangi penyebaran virus flu burung dan juga memperbaiki status konservasi burung di daerah tersebut. Hal ini membatasi potensi perdagangan spesies burungburung yang dianggap eksotik untuk memastikan juga populasi mereka tidak terancam oleh perdagangan satwa liar secara internasional. 
Kebijakan atau upaya penanggulangan kejahatan pada hakikatnya merupakan bagian integral dari upaya perlindungan masyarakat (social defence) dan upaya mencapai kesejahteraan (social welfare). Kebijakan penanggulangan kejahatan atau bisa disebut juga politik kriminal memiliki tujuan akhir atau tujuan utama yaitu "perlindungan masyarakat untuk mencapai kesejahteraan masyarakat". Kebijakan penanggulangan kejahatan (criminal policy) itu sendiri merupakan bagian dari kebijakan penegakan hukum (law enforcement policy). Kebijakan penegakan hukum merupakan bagian dari kebijakan social (social policy) dan termasuk juga dalam kebijakan legislatif (legislative policy). Politik kriminal pada hakikatnya juga merupakan bagian integral dari kebijakan sosial yaitu kebijakan atau upaya untuk mencapai kesejahteraan sosial.

Upaya penanggulangan kejahatan atau tindak pidana, seperti halnya penanggulangan tindak pidana (politik kriminal) dapat ditempuh atau dilakukan dengan menggunakan sarana kebijakan hukum pidana (penal) maupun dengan menggunakan sarana pendekatan preventif (non-penal).

\section{Kebijakan Hukum Pidana (Penal Policy)}

Kebijakan Hukum Pidana adalah suatu ilmu sekaligus seni yang mempunyai tujuan praktis untuk memungkinkan peraturan hukum positif dirumuskan secara lebih baik dan untuk memberi pedoman tidak hanya kepada pembuat undang-undang, tetapi juga kepada pengadilan yang menerapkan undangundang dan juga kepada para penyelenggara atau pelaksana putusan pengadilan.

2. Upaya Non-Penal dalam Kebijakan Penanggulangan Kejahatan

Kebijakan kriminal menggunakan sarana non-penal menitik beratkan pada sifat preventif (pencegahan/ penangkalan/ pengendalian) sebelum kejahatan terjadi. Mengingat upaya penanggulangan kejahatan lewat jalur non-penal lebih bersifat tindakan pencegahan untuk terjadinya kejahatan, maka sasaran utamanya adalah menangani faktor-faktor kondusif penyebab terjadinya kejahatan. Faktor-faktor kondusif itu antara lain berpusat pada masalahmasalah atau kondisi-kondisi sosial yang secara langsung atau tidak langsung dapat menimbulkan atau menumbuh suburkan kejahatan. Dengan demikian, dilihat dari sudut politik kriminal secara makro dan global, maka upaya non-penal menduduki posisi kunci dan strategis dari keseluruhan upaya politik kriminal.

Berdasarkan hasil wawancara selama penelitian pada Balai Konservasi Sumber Daya Alam Lampung menurut Subakir mengatakan bahwa upaya untuk menanggulangi tindak pidana Memperniagakan Bagian-Bagian Tubuh Satwa Yang Dilindungi dengan cara :

1. Upaya Preventif

Berdasarkan pasal 27 ayat 4 Peraturan Pemerintah Nomor 7 tahun 1999 tentang pengawetan jenis tumbuhan dan satwa menyebutkan tindakan preventif yang meliputi penyuluhan, pelatihan penegakan hukum bagi aparat-aparat penegak hukum dan penerbitan buku manual untuk mengidentifikasi jenis tumbuhan dan satwa yang dilindungi dan tidak dilindungi.

Upaya preventif atau pencegahan disini juga adalah upaya yang dilakukan oleh para aparat penegak hukum di Balai Konservasi Sumber Daya Alam (BKSDA) dalam penegakan atas penyimpangan yang terjadi pada satwa yang dilindungi oleh pemerintah. Beberapa penyimpangan ini adalah kepemilikan satwa yang dilindungi tanpa izin, perburuan satwa dilindungi dan penjualan satwa dilindungi secara 
ilegal. Salah satu upaya pencegahan lainnya adalah dengan menetapkan jenis-jenis satwa yang dilindungi berdasar undang-undang Nomor 5 tahun 1990 tentang Konservasi Sumber Daya Alam Hayati dan Ekosistemnya. Dalam undang-undang ini juga dijelaskan pengertian satwa liar adalah semua binatang yang hidup di darat, di air, dan di udara yang masih mempunyai sifat-sifat liar, baik yang hidup bebas maupun yang dipelihara oleh manusia. Sedangkan pengertian satwa langka adalah semua jenis sumber daya alam hewani baik yang hidup di darat, di air, dan di udara yang mana sudah jarang ditemui di habitat aslinya dan terancam punah. Pada undang- undang ini juga diatur mengenai pengawetan keanekaragaman tumbuhan dan satwa beserta ekosistemnya.

\section{Upaya Represif}

Tindakan represif yang dimaksud dalam Peraturan Pemerintah Nomor 7 tahun 1999 tentang Pengawetan Jenis Tumbuhan dan Satwa adalah tindakan penegakan hukum terhadap dugaan adanya tindakan hukum terhadap usaha pengawetan jenis tumbuhan dan satwa. Pada pasal 21 ayat 1 Undangundang Nomor 5 Tahun 1990 tentang Konservasi Sumber Daya Alam dan ekosistemnnya juga dikatakan bahwa setiap orang dilarang untuk mengambil, menebang, memiliki, mengangkut, dan memperniagakan hewan atau tumbuhan yang dilindungi atau bagian-bagiannya dalam keadaan hidup ataupun mati. Pihak yang melakukan pelanggaran dapat dijatuhi hukuman penjara dan denda bila terbukti bersalah. Namun dikatakan bahwa hukuman yang diberikan hingga saat ini belum mampu memberikan efek jera karena skalanya yang terbilang ringan sehingga membuat pelaku mengulangi perbuatannya. Selain itu juga dikarenakan besarnya keuntungan yang didapat dari memperjualbelikan satwa liar dilindungi secara ilegal.

Upaya preventif dan represif ini bisa membantu dalam mengurangi perdagangan satwa liar dilindungi, namun berbagai kekurangan dalam peraturan perundangundangan masih memberi celah bagi para pelaku untuk mengulangi perbuatannya. Beberapa faktor ini diantaranya yaitu menciptakan strategi pemasaran yang membuat satwa liar atau produk dari satwa menjadi kurang atraktif atau menarik bagi para konsumen sehingga jumlah permintaan pun menurun. Kampanyekampanye mengenai resiko yang dapat timbul dari interaksi dengan satwa liar hingga mempublikasikan ancaman terhadap kehidupan satwa liar dan kondisi tak manusiawi dalam perdagangan satwa. Hal ini dapat mengurangi ketertarikan dan meningkatkan empati para konsumen sehingga mereka juga akan berusaha untuk mengurangi pembelian terhadap satwa liar diindungi atau produk tertentu yang telah dilarang. Permintaan juga akan berkurang bila tersedia pengganti. Pada kasus burung kakaktua, individu kakaktua yang dilahirkan dan dirawat di penangkaran lebih jinak dan sehat dibanding dengan burung yang ditangkap di alam liar. Dengan kata lain, ini dapat menjadi pilihan yang lebih baik bagi para pembeli karena mereka akan memilih hewan peliharaan dengan kualitas yang lebih baik. Secara keseluruhan, contoh ini menunjukkan bahwa larangan sebenarnya juga dapat justru mengurangi efek dari upaya konservasi bila tidak dilakukan dengan strategi yang tepat.

\section{PENUTUP}

\section{A. Kesimpulan}

Berdasarkan hasil penelitian dan pembahasan pada Bab sebelumnya, maka dapat ditarik kesimpulan sebagai berikut :

1. Faktor penyebab pelaku melakukan aktifitas yaitu bermotif komersial, 
dimana mereka melakukan perburuan secara berkelompok, satu kelompok tidak harus berjumlah banyak, satu kelompok biasanya hanya terdiri dari 3 sampai 5 orang. Dari keterangan yang didapat langsung dari orang yang bersangkutan maka peneliti bisa menyimpulkan bahwa mereka melakukan perburuan karena tergiur dengan nilai harga tinggi, ditambah lagi semua bagian tubuh harimau memiliki harga yang sangat mengiurkan, dimana dari hasil perburuan yang didapat bisa menuai hasil yang sangat memuaskan.

2. Bahwa terdakwa dapat mempertanggung jawabkan perbuatannya yang dituangkan larangan apa saja yang tidak boleh dilakukan para pelaku tindak pidana perdagangan ilegal. Undang-Undang Nomor 5 Tahun 1990 Tentang Konservasi Sumber Daya Alam Hayati dan Ekosistemnya Pasal 21 ayat (2) sesuai dengan amar putusan Hakim Pengadilan Negeri Kelas I A Tanjung Karang dalam Putusan No.Reg : 1027/Pid.Sus/LH/2018/PN.Tjk. yang menyatakan terdakwa terbukti bersalah dan dijatuhkan pidana penjara selama : 3 (tiga) tahun dan hukuman denda sebesar Rp.50.000.000,- (lima puluh juta rupiah), dengan ketentuan apabila tidak dibayar diganti dengan hukuman kurungan selama 4 (empat) bulan.

3. Adapun upaya untuk menanggulangi tindak pidana Memperniagakan Bagian-Bagian Tubuh Satwa Yang Dilindungi yaitu dengan cara kebijakan hukum pidana (penal) secara represif, dan upaya non penal secara preemtif dan preventif atau pencegahan.

\section{B. Saran}

1. Bahwa salah satu faktor penyebab terjadinya tindak pidana memperniagakan bagian-bagian tubuh satwa yang dilindungi karena kurangnya sosialiasi atau pengetahuan masyarakat terhadap larangan membunuh/ menjual hewan liar. Kepada pihak Balai Konservasi Sumber Daya Alam dan juga Dinas Kehutanan agar lebih giat lagi bekerja menjalankan tugasnya dan mengatasi faktor-faktor terjadinya perdagangan ilegal di dalam masyarakat baik dengan mengadakan sosialisasi, seminar, dan penyuluhan, serta bekerja sama dengan instansi lain yang memiliki kewenangan dan hak yang sama dalam menjaga kelestarian satwa liar yang dilindungi agar tindak pidana perdagangan ilegal satwa liar dapat teratasi dan kepunahan satwa liar tidak terjadi lagi.

2. Dalam pertanggungjawaban pidana terhadap pelaku pidana sudah sesuai dengan hukum yang berlaku, hanya saja penjatuhan hukuman oleh Hakim di Pengadilan menurut saya kurang memberi efek jera terhadap pelaku. Kepada penegak hukum khususnya jaksa dan hakim untuk memberi hukuman lebih berat terhadap pelaku menangkap dan membunuh serta memperniagakan bagian-bagian tubuh satwa yang dilindungi agar pelaku dan masyarakat tahu kalau hukuman yang melarang perbuatan tersebut tidak main-main.

3. Untuk menanggulangi tindak pidana memperniagakan bagian-bagian tubuh satwa yang dilindungi salah satunya ada upaya non penal yaitu pencegahan. Kepada pihak kepolisian terkhusus Ditreskrimsus Polda Lampung harusnya lebih memaksimalkan kinerjanya sebagai aparat sekaligus penegak hukum, sehingga tidak hanya pedagang yang tertangkap melainkan pembelinya juga. Pihak kepolisian juga harus memberikan sanksi yang tegas, serta lebih menekan pertanggungjawaban pidana kepada pelaku baik itu pedagang maupun pembeli agar 
mereka para pelaku tindak pidana dapat mempertanggungjawabkan perbuatan-perbuatan yang dilakukan sesuai undang-undang yang mengatur sehingga sanksi tersebut menjadi efek jera kepada pelaku untuk tidak melakukannya lagi.

\section{DAFTAR PUSTAKA}

\section{A. Buku-Buku}

A Fatchan. 2013. Geografi Tumbuhan dan Hewan. Ombak

Barda Nawawi Arief. 2002. Beberapa Aspek Kebijakan Penegakan dan Pengembangan Hukum Pidana. Kencana Prenada Media Group, Jakarta

Romli Atmasasmita. 2010. Teori dan Kapita Selekta Kriminologi. Refika Aditama, Bandung

Supardi. 2012. Hukum Lingkungan Indonesia. Sinargrafika, Jakarta

Takdir Rahmadi. 2012. Hukum Lingkungan di Indonesia. Raja Grafindo Persada, Jakarta

Widada. 2006. Konservasi Sumber Daya Alam Hayati dan Ekosistemnya. Ditjen Perlindungan Hukum dan Konserfasi Alam dan JICA, Jakarta

\section{B. Perundang-Undangan}

Undang-Undang Republik Indonesia Nomor 5 Tahun 1990 Tentang Konservasi Sumber Daya Alam Dan Ekosistemnya;

Undang-Undang Republik Indonesia Nomor 41 Tahun 1999 Tentang Kehutanan;

Peraturan Pemerintah Nomor 7 Tahun 1999 Tentang Pengawetan Jenis Tumbuhan dan Satwa. 